We conclude that clinicians should be aware of syncope as a possible symptom in the relatively uncommon condition of papillary fibroelastoma of the tricuspid valve. Diagnosis by echocardiography followed by surgical excision of the tumor should be advised in all cases.

\section{REFERENCES}

1. Shahian DM, Labib SB, Chang G. Cardiac papillary fibroelastoma. Ann Thorac Surg 1995;59:538-41.

2. McAllister H, Fenoglio J Jr. Tumors of the cardiovascular system. Atlas of tumor pathology, 2nd series, Washington, DC: Armed Forces Institute of Pathology, 1978;15:20-5.

3. Edwards FH, Hale D, Cohen A, Thompson L, Pezzella T, Virmani R. Primary cardiac valve tumors. Ann Thorac Surg 1991;52:1127-31.

4. Woife JT III, Finck SJ, Safford RE, Persellin ST. Tricuspid valve papillary fibroelastoma: echocardiographic characterization. Ann Thorac Surg 1991;51:116-8.
5. Frumin H, O'Donnell L, Kerin NZ, Levine F, Nathan LE Jr, Klein SP. Two-dimensional echocardiographic detection and diagnostic features of tricuspid papillary fibroelastoma. J Am Coll Cardiol 1983;2:1016-8.

6. Anderson KR, Fiddler FI, Lie JR. Congenital papillary tumor of the tricuspid valve: an unusual cause of right ventricular outflow obstruction in a neonate with trisomy E. Mayo Clin Proc 1977;52:665-9.

7. Neerukonda SK, Jantz RD, Vijay NK, Narrod JA, Schoonmaker FW. Pulmonary embolization of papillary fibroelastoma arising from the tricuspid valve. Tex Heart Inst $\mathbf{J}$ 1991;18:132-5.

8. Mohan JC, Goel PK, Gambhir DS, Khanna SK, Arora R. Calcified mobile papillary fibroelastoma of the tricuspid valve: a case report. Indian Heart J 1987;39:237-9.

\title{
MULTIPLE SMALL FENESTRATIONS CREATED DURING CONSTRUCTION OF THE TOTAL CAVOPULMONARY CIRCULATION: SUBSEQUENT COURSE AND SPONTANEOUS CLOSURE
}

\author{
M. C. Sherwood, MB, BS, FRACP, G. R. Nunn, MB, BS, FRACS, and G. F. Sholler, MB, BS, FRACP, \\ Westmead, New South Wales, Australia.
}

Fenestration of the baffle between the systemic and pulmonary venous atria at the time of construction of the total cavopulmonary circulation is reported to lower morbidity and risk of takedown of the connection and decrease mortality. ${ }^{1-3}$ Cardiac output is maintained by rightto-left shunt across the fenestration and right atrial pressure is lowered, but with consequent persisting systemic desaturation. ${ }^{1-3}$ A single fenestration has usually been created. ${ }^{1-5}$ Fenestration size has most frequently been $3.5^{2}$ to $4 \mathrm{~mm}, 1,3,4$ with a corresponding crosssectional area of 9.6 to $12.6 \mathrm{~mm}^{2}$, but has varied from 2.7 $\mathrm{mm}^{3}$ to $9 \mathrm{~mm}^{4}$ with cross-sectional areas of 5.7 to 63.9 $\mathrm{mm}^{2}$. Transcatheter device closure $\mathrm{s}^{1-4}$ or surgical closure with a snare placed around the fenestration ${ }^{5}$ has been performed at variable times after the initial operation. Spontaneous closure of fenestrations has been noted, ${ }^{1,2}$ more commonly in the smaller fenestrations. ${ }^{3}$ We placed multiple small fenestrations with a total combined crosssectional area similar to that resulting from a single 3.5 to

From the Adolph Basser Institute of Cardiology, the Royal Alexandra Hospital for Children, Westmead, New South Wales, Australia.

Received for publication Sept. 6, 1995; accepted for publication Nov. 10, 1995.

J Thorac Cardiovasc Surg 1996;112:553-4

Copyright (C) 1996 by Mosby-Year Book, Inc.

$0022-5223 / 96 \$ 5.00+0 \quad \mathbf{1 2 / 5 4 / 7 1 2 5 5}$
$4 \mathrm{~mm}$ fenestration to achieve a similar oximetric and hemodynamic outcome, but in the hope that early spontaneous closure would occur, avoiding the need for further interventions.

Five patients aged 2.8 to 5.9 years had multiple small fenestrations created in the baffle at the time of total cavopulmonary connection. All operations were performed by the same surgeon. Fenestrations were created in the polytetrafluoroethylene membrane used for the right atrial lateral tunnel with the use of a $2.5 \mathrm{~mm}$ punch (Scanlan) or cut with a blade, approximately $3 \mathrm{~mm}$ apart, before the patch was incorporated in the right atrial closure. Postoperative mean right atrial pressures 24 to 48 hours after the operation and saturations at hospital discharge were recorded. The hospital stays were 7 to 19 days. All patients were evaluated electively 5 to 10 months after the procedure to establish the status of the multiple small fenestrations. Four patients were studied with transesophageal echocardiography and one patient with transthoracic echocardiography. Saturations with the patients breathing air were determined by transcutaneous pulse oximetry at follow-up.

Results are presented in Table I and include diagnosis and previous operation, fenestration size and number, postoperative right atrial pressures and saturations, and the status of the fenestrations and saturations at followup. Transesophageal echocardiography provided excellent imaging of the baffle wall permitting delineation of each of the small fenestrations when present. In patient 1 the 
Table I. Diagnoses, perioperative data, and postoperative follow-up

\begin{tabular}{|c|c|c|c|c|c|c|c|c|c|c|c|}
\hline $\begin{array}{c}\text { Patient } \\
\text { No. }\end{array}$ & $\begin{array}{l}\text { Age } \\
(y r)\end{array}$ & $\begin{array}{c}\text { Diagnosis and } \\
\text { previous } \\
\text { operation }\end{array}$ & $\begin{array}{c}\text { Fen size } \\
(\mathrm{mm})\end{array}$ & Fen No. & $\begin{array}{c}\text { Total } \\
\text { CSA } \\
\left(\mathrm{mm}^{2}\right)\end{array}$ & $\begin{array}{c}\text { Mean RAP } \\
(m m I g)\end{array}$ & $\begin{array}{l}\text { Postop. } \\
\text { sat (\%) }\end{array}$ & $\begin{array}{c}\text { Time to } \\
\text { follow-up } \\
\text { (mo) }\end{array}$ & $\begin{array}{c}\text { Follow-up } \\
\text { sat }(\%)\end{array}$ & $\begin{array}{l}\text { Study } \\
\text { echo }\end{array}$ & $\begin{array}{l}\text { Status } \\
\text { MSF } \\
\text { (No.) }\end{array}$ \\
\hline 1 & 5.5 & $\begin{array}{r}\text { DILV, VSD, } \\
\text { TGA, SPS }\end{array}$ & 2 & 2 & 6.2 & 20 & 85 & 10 & 85 & TEE & Closed \\
\hline 2 & 2.8 & $\begin{array}{l}\text { TGA, VSD, } \\
\text { PS, atrial } \\
\text { septectomy }\end{array}$ & 2 & 4 & 12.6 & 12 & 88 & 9 & 95 & TEE & Closed \\
\hline 3 & 4.2 & $\begin{array}{l}\text { DILV, } \\
\text { LTGA, } \\
\text { VSD, PAB, } \\
\text { BDG }\end{array}$ & 2.5 & 2 & 9.8 & 17 & 91 & 8 & 96 & TEE & Closed \\
\hline 4 & 5.9 & $\begin{array}{c}\text { DORV, VSD, } \\
\text { PAB, BDG }\end{array}$ & 2.5 & 3 & 14.7 & 12 & 88 & 7 & 91 & TEE & $\begin{array}{l}\text { Open } \\
\text { (3) }\end{array}$ \\
\hline 5 & 3.8 & $\begin{array}{r}\text { DILV, TGA, } \\
\text { VSD, PAB }\end{array}$ & 2.5 & 3 & 14.7 & 15 & 85 & 5 & 90 & TTE & $\begin{array}{l}\text { Open } \\
\text { (3) }\end{array}$ \\
\hline
\end{tabular}

Fen, Fenestration; $C S A$, cross-sectional area; RAP, right atrial pressure; sat, saturation; $M S F$, multiple small fenestrations; $D I L V$, double-inlet left ventricle; $V S D$, ventricular septal defect; $T G A$, transposition of the great arteries; SPS, subpulmonary stenosis; $P S$, pulmonary stenosis; $L T G A$, levo-transposition of the great arteries; $P A B$, pulmonary artery banding; $B D G$, bidirectional Glenn shunt; $D O R V$, double-outlet right ventricle; $T E E$, transesophageal echocardiography; TTE, transthoracic echocardiography.

early postoperative period was complicated by clot formation in the left ventricular apex, and the patient received and continues to receive warfarin sodium. The thrombus spontaneously diminished in size and disappeared. No evidence of embolism was apparent at any stage. Recurrent pericardial effusions in the postoperative period necessitated creation of a pericardial window. Transesophageal echocardiography at 10 months demonstrated the fenestrations to be closed, but the transcutaneous saturation was $85 \%$. Peripheral venous injection of agitated isotonic saline solution in the left arm resulted in the immediate appearance of contrast in the pulmonary venous chamber, suggesting the presence of a systemic venous connection directly to the left atrium. In patient 5 the proximal left coronary artery was thought to be damaged during dissection around the pulmonary artery for its ligation, and the left internal thoracic artery was grafted to the left coronary artery during the repair. Cardiac catheterization performed 5 months after the operation demonstrated complete obstruction of the internal thoracic artery with normal filling of the left coronary artery from the aorta.

Multiple small fenestrations ( 2 to $2.5 \mathrm{~mm}$ ) were created in our small group of patients, and in three of five patients the fenestrations had closed spontaneously at 8,9 , and 10 months after the operation, including the patient who was receiving full anticoagulant therapy. In two of these three patients the fenestrations were the smaller $(2 \mathrm{~mm}$ diameter) of those placed. These three patients had fenestrations with a smaller total cross-sectional area and were those with the longest time to follow-up. In patients with persisting patency of the multiple small fenestrations, all the fenestrations were open.

We believe multiple small fenestrations in the total cavopulmonary circulation may have a high rate of spontaneous closure, avoiding the need for subsequent intervention, and time may play a role in the rate of closure. Residual desaturation should not be assumed to be due to surgically created communications.

We thank Drs. Richard Hawker, Steve Cooper, and K. C. Lau for access to their patients for follow-up review.

\section{REFERENCES}

1. Bridges ND, Mayer JE, Lock JE, et al. Effect of baffle fenestration on outcome of the modified Fontan operation. Circulation 1992;86:1762-9.

2. Mavroudis C, Zales VR, Backer CL, Muster AJ, Latson LA. Fenestrated Fontan with delayed catheter closure: effects of volume loading and baffle fenestration on cardiac index and oxygen delivery. Circulation 1992;86(Suppl):II85-92.

3. Orsmond GS, Shaddy RE, Day RW, et al. The results of spontaneous and clamshell umbrella closure of the fenestrated Fontan (abstract). J Am Coll Cardiol 1995;25:350A.

4. Bridges ND, Lock JE, Castaneda AR. Baffle fenestration with subsequent transcatheter closure: modification of the Fontan operation for patients at increased risk. Circulation 1990;82: 1681-9.

5. Laks H, Pearl JM, Drinkwater DC, et al. Partial Fontan: advantages of an adjustable interatrial communication. Ann Thorac Surg 1991;52:1084-94. 